\title{
Dietary Acid Load and Its Interaction With IGF1 and IL6 Polymorphisms on Metabolic Traits Among Postmenopausal Women
}

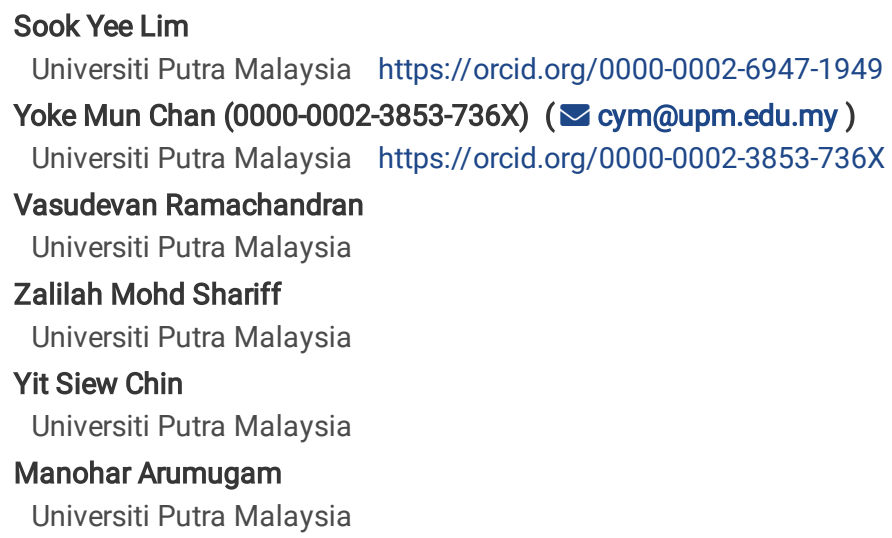




\section{Abstract}

Background: Despite considerable work has been done to understand the underlying disease mechanisms by elucidating its genetic etiology, still the pathophysiology of the metabolic syndrome remains unclear. While numerous studies have shown that Insulin growth factors-1 (IGF1), Interleukin-6 (IL-6) gene polymorphisms and high dietary acid load (DAL) were related to undesirable profile of metabolic traits; it remains controversial whether DAL is associated with genetic polymorphisms or risk of metabolic traits. Thus, the objective of this study was to explore the effects of DAL, IGF1 and IL6 gene polymorphisms and their potential diet-gene interactions on metabolic traits.

Methods: A total of 211 community-dwelling postmenopausal women were recruited. DAL was estimated using potential renal acid load (PRAL). Blood was drawn for biochemical parameters and DNA was extracted and Agena ${ }^{\circledR}$ MassARRAY was used for genotyping analysis to identify the signaling of IGF1 (rs35767, rs7136446) and IL6 (rs1800796) polymorphisms. Interactions between diet and genetic polymorphisms were assessed using hierarchical multiple linear regression analysis.

Results: Mean age of respondents was $67 \pm 6.7$ years. A total of $68.2 \%, 59.2 \%, 49.3 \%, 23.2 \%, 23.2 \%$ and $10.9 \%$ had elevated systolic blood pressure (SBP), hyperglycemia, excessive waist circumference (WC), diastolic blood pressure (DBP), triglycerides (TG) and low high-density lipoprotein (HDL), respectively. DAL was positively associated with FBG $(\beta=0.147, p<0.05)$ and there was significant interaction effect between DAL and IL6 with SBP ( $\beta=0.19, p=0.041)$. On the other hand, there were no significant main effects of DAL and single nucleotide polymorphisms (SNPs) (rs35767, rs7136446 and rs1800796) on SBP, DBP, WC, TG or HDL and cholesterol ratio. There were also no significant interaction effects between DAL and IGF1 SNPs (rs35767 and rs7136446) on SBP, DBP and FBG, TG, HDL and cholesterol ratio.

Conclusion: These findings did not support the interaction effects between DAL and IGF1 and IL6 SNPs (s35767, rs7136446 and rs1800796) on metabolic traits, except for SBP. Besides, higher DAL was associated with higher FBG, allowing us to postulate high DAL is a potential risk factor for diabetes. Future research delineating foods that contribute to high DAL, and how IL6 gene polymorphism influences the association with DAL on hypertension are warranted.

\section{Background}

Metabolic syndrome (MS) is a cluster of inter-related and heritable metabolic traits, which collectively impart unsurpassed risk for type 2 diabetes mellitus (T2DM) and atherosclerotic cardiovascular disease [1]. Prevalence of MS in most countries in the Asia-pacific region was higher in females [2], attributed to various cultural factors including stress and low socio-economic status [3]. Besides gender, etiology of MS is likely multifactorial, and involves the interplay among lifestyle behaviour, ageing, obesogenic environments and genetic susceptibility [4], with the later had ignited the interest for numerous genetic studies in Asia to gain insight into the genetic basis of MS and its component traits [5-11]. Despite lifestyle is a well-known determinant for the development of MS, genetic variants, especially when it involves functional polymorphisms in the promoter regions of the genes, may alter the function and expression of genes that are associated with energy intake and energy expenditure [12].

To the best of knowledge, the genes involved with the pathophysiology of MS have not been fully elucidated. On the other hand, gene association studies and genome-wide association studies had identified that insulin growth factors 1 (IGF1) and interleukin 6 (IL6) gene polymorphism are responsible for metabolic traits. Pro-inflammatory cytokines (IL6) plays a major role in modulating lipid metabolism, adipocytes functions and insulin sensitivity [13] besides its anti-inflammatory and regenerative features [7]. The previous study has shown that IL6 gene -587 G/A polymorphism would increase the risk of T2DM in G allele carriers closed to 1.3 fold as compared to those with C allele [8]. The SNPs rs1800797 (-597 G/A), rs1800796 $(-572 \mathrm{G} / \mathrm{C})$ and rs1800795 (-174 G/C) that are located in the promoter region of IL6, on the other hand, were associated with obesity and metabolic traits in different ethnic groups [12]. The rs1800796 polymorphism was associated with high insulinogenic index in Danes [14], hyperglycaemia in Mexicans [15] and hypertension and obesity in Asians [16, 17].

IGF1 plays major roles in main pathways in the progression of metabolic traits, such as progression of T2DM complications [18] and also the development of cardiovascular diseases [19]. It is an important growth factor that linked with various biological systems, especially in cell proliferation, differentiation, survival and maturation [20]. The SNP rs35767 is known to contribute to the development of diabetes in various population. A study showed TT genotype of rs35767 increased 1.92 fold and 1.77 fold of risk for T2DM and diabetic retinopathy in the Chinese Han population, respectively [21]. Besides, CC genotype of rs7136446 had higher body mass index and body fat percentage than TT and CT genotypes [22] but lacking evidence on other metabolic traits [23]. Hence, the roles of IGF1 gene polymorphisms and disease susceptibility are evident and deserved further studies.

Postmenopausal women are more likely to develop metabolic traits, such as obesity and diabetes as compared with men. Hormonal changes and agerelated changes in body composition especially increased in total body fat and decreased in lean body mass may cause a disturbance in glucose metabolism and insulin sensitivity [24]. However, inconclusive findings were reported whereby the age of menopause was not related to the occurrence of diabetes among Chinese postmenopausal women [25] in China and Italy [26], probably attributed to methodological issue [25, 27].

Several studies had examined that high intake of acidogenic foods including animal products and low intake of alkaline foods including fruits and vegetables might cause excess in endogenous acid production which in turn leads to metabolic acidosis [28], and increase the risk of metabolic traits including obesity [29], hypertension [30] and diabetes mellitus [31], with inconsistencies reported in others [32, 33]. These inconsistencies could be 
attributed to differences in the sample sizes, genetic heterogeneous and dietary assessments. To the best of knowledge, this is the first study that attempts to examine the interaction between dietary acid load (DAL) with genetic polymorphism and the development of metabolic traits among postmenopausal Chinese women. We aimed to explore the effects of DAL, IGF1 and IL6 gene polymorphisms and their potential diet-gene interactions on systolic blood pressure (SBP), diastolic blood pressure (DBP), fasting blood glucose (FBG), waist circumference and lipid profile.

\section{Methods}

\section{Study Design and Respondents}

This was an analytical cross-sectional study conducted on community-dwelling postmenopausal women in Kuala Lumpur and Selangor, Malaysia. The methodology of the study has been published elsewhere [34]. Briefly, a total of 211 eligible Malaysians, at least 5 years postmenopausal and absence from severe diseases were recruited based on two-stage sampling technique. Ethical approval was obtained from the Ethics Committee for Research Involving Human Subjects (project reference number: FPSK (FR16) P019) with all respondents provided written informed consent prior to study enrollment.

\section{Sociodemographic and physical activity}

Sociodemographic information was ascertained using a pre-tested structured questionnaire as discussed elsewhere [34]. The physical activity level of respondents was evaluated using the Global Physical Activity Questionnaire (GPAQ) [35], with the level of physical activity was classified according to Kyu et al. [36].

\section{Physical measurement}

Height of respondents was measured using a portable SECA stadiometer while the weight was measured at respondents' fasting state using a TANITA digital weighing scale. Body Mass Index of respondents was computed as the ratio of weight $(\mathrm{kg})$ to height in meter squared $\left(\mathrm{m}^{2}\right)$, and the WHO 2000 [37] classification was used to classify BMI. Waist circumferences (WC) of respondents was measured using Lufkin anthropometric measuring tape while blood pressure of respondents was measured using a Digital Automatic BP monitor (OMRON HEM-907, Japan).

\section{Blood collection and biochemical measurement}

Fasting blood samples were collected from antecubital veins in EDTA (Becton Dickinson, NJ) and plain tubes by certified phlebotomists. The tubes were immediately placed in the icebox and were transferred to an analytical laboratory at which the blood samples were separated into plasma (glucose, vitamin D and DNA analysis) or serum (lipid profile analysis) and stored at $-20^{\circ} \mathrm{C}$ until subsequent analyses. Fasting plasma glucose was determined by Hexokinase method using the Olympus AU analyzer (Beckman-Coulter, Inc., Fullerton, CA, USA) while fasting serum lipid profiles (total cholesterol, triglyceride, HDL-C and LDL-C) were determined using commercially available kits on a Hitachi 704 Analyzer, which is serviced by Roche Diagnostics. Total cholesterol and triglyceride were analyzed according to Cholesterol Oxidase/ Peroxidase and Glycerol Phosphate Oxidase/ Peroxidase method, respectively. On the other hand, HDL-C was measured by direct HDL method while LDL-C was estimated indirectly using the Friedewald formula. On the other hand, serum levels of $25(\mathrm{OH})$ vitamin D was determined by using the Siemens ADVIA Centaur Vitamin D Total assay (Siemens, Tarrytown, NY, USA), with the analytical measuring range between 4.2 to $150 \mathrm{ng} / \mathrm{mL}$ (10.5 154 to $375 \mathrm{nmol} / \mathrm{L})$.

\section{Estimation of Dietary Acid Load}

Dietary intakes of respondents were assessed using a validated semi-quantitative food frequency questionnaire (sFFQ) adapted from the Malaysian Adult Nutrition Survey 2014 [38]. The sFFQ covers 165 food items frequently consumed among Malaysian, along with their standard portion sizes. After receiving detailed instructions from researchers, respondents indicated the typical frequency of consumption of foods and average amount (in household measures, eg cup, bowl, spoons), to allow the estimation of food intake over the past month [39]. Portion sizes were then converted to grams, based on the published household measurement. The validity and reliability of this questionnaire among Malaysian have been assessed previously [38]. Nutrients data (protein, phosphorus, potassium, magnesium and calcium) were then analysed using Nutritionist Pro ${ }^{\mathrm{TM}}$ Diet Analysis (Version 3.2, 2007, Axxya Systems, Stafford, TX, USA) software, with Nutrient Composition of Malaysia Foods (Tee, 1997) and Singapore Food Composition Database (Energy and Nutrient Composition of Food, 2011) as the primary databases. Dietary Acid Load of respondents was estimated according to potential renal acid load (PRAL) ${ }^{33}$ equation as below:

$\operatorname{PRAL}(\mathrm{mEq} / \mathrm{d})=0.49$ protein $(\mathrm{g} / \mathrm{d})+0.037$ phosphorus $(\mathrm{mg} / \mathrm{d})-0.021$ potassium $(\mathrm{mg} / \mathrm{d})$

-0.026 magnesium $(\mathrm{mg} / \mathrm{d})-0.013$ calcium $(\mathrm{mg} / \mathrm{d})$

\section{SNP selection, genotyping and quality control analysis}

Candidate genes and SNPs were chosen from previously published literature which showed associations with metabolic traits [12, 15, 16, 22, 40-43]. IGF1 (rs35767, rs7136446) and IL6 gene (rs1800796) polymorphisms were selected in this study. SNPs sequences were referred from the https://www.ncbi.nlm.nih.gov/snp/ website. Genomic DNA was extracted from whole blood samples (EDTA tube) using a commercially available DNA extraction kit (QIAamp DNA Blood Mini Kit Qiagen, Hilden, Germany) according to the standard protocol. The extracted DNA concentration was 
quantified using a Spectrophotometer (Nanodrop, USA) and the qualities of the extracted DNA were assessed using $0.8 \%$ agarose gel electrophoresis. After all, samples showed good quantity and quality of DNA, each genotyping was further analyzed using Agena ${ }^{\circledR}$ MassARRAY. After the SNP detection process, Typer Analyzer was used to analyze the output data from Agena® Massaray.

\section{Statistical analyses}

Statistical analyses were performed using IBM SPSS 22 (SPPS Inc. Chicago, USA) with the level of significance set at $p<0.05$. Hardy-Weinberg equilibrium (HWE) test for genotypic distribution was examined using the Hardy-Weinberg equilibrium exact test. Due to less than $5 \%$ of the respondents have TT (rs35767), CC (rs7136446) and CC (rs1800796) genotypes, they were combined with the heterozygous groups (rs35767: TT + CT; rs7136446: CC + CT; rs1800796: CC + CG) for further analysis. Prior to analysis, data quality was performed via SPSS to remove outliers, handling missing values and testing normality.

Descriptive data were presented as mean \pm SD and range, or percentage. Metabolic traits cut off points were followed Harmonized criteria [43] considering it is the most updated and recommended by Joint Interim Statement (JIS) committees and suitable for the Asian population [43-45]. Next, comparisons of respondents' characteristics between two groups genotypes of three SNPs were completed using independent Student's t-test.

Furthermore, 18 models of three-step hierarchical multiple linear regression analysis were employed to test the contribution of variables as well as to determine the direct and interaction effects of DAL and genetic polymorphisms with each metabolic trait (SBP, DBP, WC, FBG, TG, and HDL and cholesterol ratio). Step one was used to determine the association between adjusted variables and metabolic traits while step two assessed the association between the DAL and gene polymorphism (rs35767, rs7136446 and rs1800796) on the dependent variable (SBP, DBP, WC, FBG, TG, and $\mathrm{HDL}$ and cholesterol ratio). These were followed by step three which aimed to add interaction term (DAL*gene polymorphism) and to determine the interaction effect of DAL with gene polymorphism for each metabolic trait.

\section{Results}

\section{General characteristics}

Table 1 presents the general characteristics of the respondents. The mean age of the respondents was $66.7 \pm 6.6$ years old while the average years of menopause were more than 15 years. A majority of the respondents had attained a lower secondary education with the average years of education of $8 \pm 4.6$ years. Approximately $99 \%$ were insufficiently active and low active while less than $2 \%$ were moderately active. According to the harmonized metabolic syndrome criteria $[43,45]$, approximately half of the respondents had abdominal obesity, more than two-third had elevated SBP, near to onefourth had elevated DBP while more than half of the respondents had high blood glucose. Mean PRAL score was $13.8 \pm 19.1 \mathrm{mEq} / \mathrm{day}$. Among the respondents, the genotype distributions for the two IGF1 polymorphisms were TT + CT: $52.1 \%$ and CC: $47.9 \%$ (rs35767); CT + CC: $32.7 \%$ and TT: $67.3 \%$ (rs7136446). IL6 gene rs1800796 polymorphism was CC + CG: $44.1 \%$ and GG: $55.9 \%$.

\section{Demographic, clinical and biochemical characteristics according to SNPs rs35767, rs7136446 and rs1800796}

Table 2 outlines the demographic, clinical and biochemical characteristics of the postmenopausal women according to the genotypes of the SNPs rs35767, rs7136446 and rs1800796. There were no significant differences on age, duration of menopause, duration of education and BMI across the SNPs. Similarly, metabolic traits and lipid profile (WC, SBP, DBP, blood glucose, total cholesterol, HDL, LDL and triglycerides) were comparable between major allele for each genotype.

\section{Contribution of variables on metabolic traits}

Table 3 presents step one of the three-step hierarchical regression analysis, highlighted the contribution of adjusted variables on each metabolic trait. In the SBP model, age, BMI and total cholesterol were positively associated with SBP. Thus, the higher the BMI, total cholesterol and more advanced age, the higher will their SBP be. Similarly, there were positive associations between BMI and total cholesterol with diastolic blood pressure. On the other hand, FBG, SBP and TG were positively associated with WC while years of education were negatively associated with WC. As for fasting blood glucose, age and BMI were positively associated while total cholesterol was negatively associated with FBG, indicating the lower the total cholesterol, the higher the FBG. Meanwhile, HDL and cholesterol ratio and WC were positively associated with TG while serum $25(\mathrm{OH})$ vitamin $\mathrm{D}$ was negatively associated with TG. Finally, yet importantly, HDL and cholesterol ratio was positively associated with TG level but was negatively associated with age. Overall, these results indicated that most of the adjusted variables contributed significantly to the metabolic traits.

\section{Direct effects of DAL and genetic polymorphisms on metabolic traits}

Table 3 depicts the Hierarchical Linear regression analyses on gene-DAL interaction effects on metabolic traits of the respondents. There were no significant main effects of DAL and SNPs (rs35767, rs7136446 and rs1800796) on SBP, DBP, WC, TG and HDL and cholesterol ratio. On the other hand, PRAL was positively associated with FBG.

\section{Gene-diet interaction for metabolic traits}


There were no significant interaction effects between PRAL and IGF1 (rs35767 and rs7136446) SNPs on SBP, DBP and FBG, TG, or HDL and cholesterol ratio (Table 3). On the other hand, the interaction between PRAL and IL6 gene polymorphism was associated significantly with SBP ( $\beta=$ $0.19, p=0.041)$. As shown in Figure 1, lower SBP was observed as correspondence to lower PRAL among the respondents with CC genotypes. On the other hand, among the $\mathrm{G}$ allele carriers ( $\mathrm{CG}+\mathrm{GG}$ ), we observed that the higher the PRAL, the lower the SBP.

\section{Discussion}

There was a significant interaction effect between DAL and SNP rs1800796 with SBP trait. The present study showed that DAL may strengthen the effect of SNP rs 1800796 with SBP, with the effect of GG + CG genotypes being more pronounced among those who consumed high DAL, to have higher SBP. As this was the first study investigating the interaction effect between DAL and SNP rs1800796 on SBP, potential mechanism on how this occurs is unknown. It is hypothesized that SNP rs 1800796 with GG + CG genotypes carriers may have a higher risk of hypertension if the high acidic diet is habitually consumed. Nevertheless, more works are needed before a confirmation can be drawn.

On the other hand, contrary to expectations, this study did not find significant direct effect between DAL and SBP. The result was in contrast to the existing evidence [46-48]. Dehghan et al. (2019) reported that higher DAL (assessed by PRAL) was associated with $0.97 \mathrm{~mm} \mathrm{Hg}$ increase in SBP [46] while Chen et al (2019) demonstrated that higher PRAL has 14\% increased risk of hypertension [48]. A possible explanation for the discrepancy may be attributed to current study was confined in cross-sectional study design and could not be able to assess the long term effect of DAL on SBP. Besides, the inconsistent result may due to different genetic makeup for different ethnicity. There was the reason to conduct this study to discover the different phenotypic (SBP) responses to a specific diet (DAL) depending on the genotype (IL6 and IGF1) of the postmenopausal Chinese women.

The finding of the current study did not support the association between SNP rs1800796 and hypertension as reported earlier [49]. A meta-analysis of case-control studies found that the SNP rs1800796 with the G allele carriers have a higher risk of developing hypertension than C allele [49]. We do not have an exact explanation for this, but it is postulated that differences in the recruited population may have contributed to the variation.

This study confirmed the positive association between DAL and FBG among postmenopausal women, which was consistent with previous research [50-53]. The mechanism on the association between DAL and risk of type 2 diabetes has not yet been completely clarified, with several potential mechanisms were proposed. Firstly, high DAL may cause metabolic acidosis. The lower (acidic) blood pH may reduce uptake of glucose by muscle, disrupt the insulin binding to its receptor, and further inhibit the insulin signaling pathway [54]. Secondly, high DAL may increase cortisol secretion and may consequently lead to visceral obesity and insulin resistance [55]. Thirdly, acid-base homeostasis may influence calcium and magnesium absorption in the kidney [56] and consequences of serum calcium and magnesium were related to insulin sensitivity [57, 58]. Finally, yet importantly, metabolic acidosis may reduce the secretion of IGF-I [59] and inhibit insulin sensitivity [60]. On the other hand, this finding was incongruent with a longitudinal study involved 911 older non-diabetic community-dwelling Swedish men [33]. The inconsistencies in findings may be attributed to the different ethnicity, geographical distribution, age, gender of the respondents as well as the cut-off used to determine the risk of diabetes. Further investigations on these aspects are warranted.

The current findings were unable to show the evidence on the association between IGF1 and IL6 SNPs (rs35767, rs7136446 and rs1800796) with FBG. In contrast to earlier findings, a meta-analysis reported a significant association between the SNP rs1800796 G allele and increased risk of T2DM among Asians [61]. Similar to SNP rs35767, previous research supports the association between SNP rs35767 and insulin resistance with C allele that may have a protective effect in T2DM $[40,43]$. On the other hand, SNP rs7136446 was not commonly reported among the Asian population. Proposed mechanisms on the relationship between IGF1 and risk of diabetes include IGF1 has the homology structure with insulin and is similar to insulin function that regulates hormone for insulin resistance and subsequently regulates glucose homeostasis [62]. The varying results between previous research and the current study may due to the demographic differences as discussed above. However, the major strength of the current study is the strict recruitment criteria, which were the same ethnicity of respondents with at least 5 years of menopausal as well as without severe diseases were applied.

This study did not support the interaction effect between DAL with gene IL6 and IGF1 on FBG, regardless of whether potential control variables were adjusted. As this is the first interaction study to investigate the DAL and SNPs on FBG, the mechanism on such the association is still unclear. The insignificant interaction result may indicate that the modification between DAL and SNPs are less important than other factors in determining FBG. Further investigation on other dietary patterns (such as Western diet, high-fat diet or Mediterranean Diet) with gene IL6 (rs1800796) and IGF1 (rs 35767 and rs7136446) polymorphisms is needed.

We investigated the potential direct effect between DAL and metabolic traits, SNPs with metabolic traits, and potential interactions between DAL and genetic polymorphisms in relation to metabolic traits. There were no significant interactions between DAL with IL6 and IGF1 SNPS on FBG, obesity and lipid traits. In addition, there were no significant direct effects between DAL on WC or lipid traits. Recent studies also showed that the findings of the association between DAL and obesity traits are contradictory. While there were positive associations between DAL and obesity traits in several studies [30,63-66], there were lacking such associations in others [67]. On the other hand, studies on the associations between DAL and lipid traits were scarce. The current findings failed to confirm the association between DAL and waist circumference or lipid traits. Other unhealthy dietary patterns (such as high animal fat/calories food and snack/fast food) or lifestyle (inactive lifestyle) are more prominent contributors to obesity and lipid traits (64-67). 
IL6 is a pro-inflammatory cytokine and it plays an important role in diseases development. Previous research on the association between SNP rs1800796 and waist circumference or risk of obesity had been inconsistent [12,68-71]. The current study unable to draw a definite conclusion on the associations between SNP rs1800796 with waist circumference and lipid traits among the subjects. The discrepancies in findings may be due to different ethnic populations as variations in SNPs exist according to ethnicities and more studies are recommended.

We were not able to confirm the association between SNPs rs35767 and rs7136446 with waist circumference and lipid traits. Nevertheless, a significant association between SNP rs35767 and total fat was observed earlier, whereby older white women with CC genotype of SNP rs35767 had $3 \%$ more trunk fat and $2 \%$ more total fat than those with $\mathrm{C} / \mathrm{T}$ [42]. On the other hand, older black women with CC genotype had $3 \%$ less total lean mass and 3\% less muscle mass than their TT genotype. The overall finding demonstrated older white women and older black women with the CC genotype of SNP rs35767 have lower muscle function [42]. However, the above study was limited to the Caucasian population, with such study is lacking for non-Caucasian. An earlier study showed individual with CC genotype of SNP rs7136446 had higher BMI and body fat values than TT and CT genotypes. However, such a result was not significant after adjusted for covariates [22]. The dearth of information signifies more works are needed.

Some limitations of this study should be noted. Firstly, due to budgetary reasons, serum IGF1 and IL6 levels were not measured. Elevation of IGF1 and IL6 levels might be able to explain better on the gene-diet interaction with metabolic traits. Secondly, it was a cross-sectional study and hence unable to determine the causal and effect relationship between variables. Future studies should include the investigation of long-term changes of DAL on FBG and DAL/IL6 level on SBP. On the other hand, the consideration to adjust potential confounding factors in the analysis to minimize the effects contributed by confounding factors was seen as one of the study strengths.

\section{Conclusion}

To the best of our knowledge, this was the first study reporting gene-diet interaction between DAL with IGF1 and IL6 gene polymorphisms on obesity, hypertension, blood glucose and lipid traits. This study showed that higher consumption of an acidity diet might increase blood glucose. Besides, the significant gene-diet interaction between DAL and IL6 on SBP trait may provide useful information in planning for personalized nutrition.

\section{Abbreviations}

BMI: body mass index; BMD: bone mineral density; BTM: bone turnover marker; CTX1: collagen type 1 cross-linked C-telopeptide; DEXA: dual-energy Xray absorptiometry; ERB: estrogen receptor beta; FFQ: food frequency questionnaire; GPAQ: Global Physical Activity Questionnaire; IL6: Interleukin 6; MANS: Malaysian Adult Nutrition Survey; NEAP: net endogenous acid production; NACSCOM: National Council of Senior Citizens Organizations Malaysia; PRAL: potential renal acid load; PINP: procollagen type I N-propeptide; SNP: single nucleotide polymorphism; TGF- $\beta 1$ : transforming growth factor- $\beta 1$

\section{Declarations}

\section{Ethics approval and consent to participate}

The study protocol was approved by the Ethics Committee for Research Involving Human Subjects with project reference number was FPSK (FR16) P019. Written informed consent was obtained from each participant.

\section{Consent for publication}

Not applicable.

\section{Availability of data and materials}

Not applicable.

\section{Competing interests}

The authors declare that they have no competing interests.

\section{Funding}

This research was funded by Fundamental Research Grant Scheme Ministry of Higher Education, Malaysia (grant number 04-01-15-1739FR) and Putra Grant UPM (grant number GP-IPS/2017/9576200)

\section{Authors' contributions}

YMC, VR, MSZ, YSC, MA and SYL designed and implemented the study. VR designed the genetic study. SYL performed genotyping and statistical analysis. SYL, YMC and VR prepared the manuscript and revised it. YMC supervised the overall project. All authors read and approved the final version of the manuscript. 
We thank the postmenopausal volunteers who participated in the studies. The study was conducted as a PhD thesis; supported by Universiti Putra Malaysia.

\section{References}

1. Abou Ziki MD, Mani A. Metabolic syndrome: genetic insights into disease pathogenesis. Curr Opin Lipidol. 2016;27(2):162-71.

2. Ranasinghe $P$, Mathangasinghe $Y$, Jayawardena R, Hills A, Misra A. Prevalence and trends of metabolic syndrome among adults in the asia-pacific region: a systematic review. BMC public health. 2017;17(1):101.

3. Pucci G, Alcidi R, Tap L, Battista F, Mattace-Raso F, Schillaci G. Sex-and gender-related prevalence, cardiovascular risk and therapeutic approach in metabolic syndrome: A review of the literature. Pharmacological research. 2017;120:34-42.

4. Vimaleswaran KS, Loos RJ. Progress in the genetics of common obesity and type 2 diabetes. Expert Rev Mol Med. $2010 ; 12: 07$.

5. Cho YS, Go MJ, Kim YJ, Heo JY, Oh JH, Ban H-J, et al. A large-scale genome-wide association study of Asian populations uncovers genetic factors influencing eight quantitative traits. Nature genetics. 2009;41(5):527-34.

6. Kim YJ, Go MJ, Hu C, Hong CB, Kim YK, Lee JY, et al. Large-scale genome-wide association studies in East Asians identify new genetic loci influencing metabolic traits. Nature genetics. 2011;43(10):990.

7. Hunter CA, Jones SA. IL-6 as a keystone cytokine in health and disease. Nat Immunol. 2015;16(5):448-57.

8. Yin YW, Sun QQ, Zhang BB, Hu AM, Liu HL, Wang Q, et al. Association between the interleukin- 6 gene $-572 \mathrm{C} / \mathrm{G}$ polymorphism and the risk of type 2 diabetes mellitus: a meta-analysis of 11,681 subjects. Ann Hum Genet. 2013;77(2):106-14.

9. Indulekha K, Surendar J, Anjana RM, Geetha L, Gokulakrishnan K, Pradeepa R, et al. Metabolic obesity, adipocytokines, and inflammatory markers in Asian Indians-CURES-124. Diabetes Technol Ther. 2015;17(2):134-41.

10. Supriya R, Tam BT, Yu AP, Lee PH, Lai CW, Cheng KK, et al. Adipokines demonstrate the interacting influence of central obesity with other cardiometabolic risk factors of metabolic syndrome in Hong Kong Chinese adults. PLoS One. 2018;13(8):e0201585.

11. Parvaresh Rizi E, Teo Y, Leow MK, Venkataraman K, Khoo EY, Yeo CR, et al. Ethnic Differences in the Role of Adipocytokines Linking Abdominal Adiposity and Insulin Sensitivity Among Asians. J Clin Endocrinol Metab. 2015;100(11):4249-56.

12. Boeta-Lopez K, Duran J, Elizondo D, Gonzales E, Rentfro A, Schwarzbach AE, et al. Association of interleukin-6 polymorphisms with obesity or metabolic traits in young Mexican-Americans. Obes Sci Pract. 2018;4(1):85-96.

13. Ronti T, Lupattelli G, Mannarino E. The endocrine function of adipose tissue: an update. Clin Endocrinol (0xf). 2006;64(4):355-65.

14. Hamid YH, Rose CS, Urhammer SA, Glumer C, Nolsoe R, Kristiansen OP, et al. Variations of the interleukin-6 promoter are associated with features of the metabolic syndrome in Caucasian Danes. Diabetologia. 2005;48(2):251-60.

15. Ramirez-Lopez G, Portilla-de Buen E, Sanchez-Corona J, Salmeron-Castro J, Mendoza-Carrera F. Interleukin-6 polymorphisms are associated with obesity and hyperglycemia in Mexican adolescents. Arch Med Res. 2013;44(1):62-8.

16. Ma H, Sun G, Wang W, Zhou Y, Liu D, Tong Y, et al. Association between interleukin-6-572 C> G and-174 G>C polymorphisms and hypertension: a meta-analysis of case-control studies. Medicine. 2016;95(2).

17. Yang X, Feng L, Li C, Li Y. Association of IL-6-174G > C and -572C > G polymorphisms with risk of young ischemic stroke patients. Gene. 2014;539(2):258-62.

18. Bazzaz JT, Amoli MM, Taheri Z, Larijani B, Pravica V, Hutchinson IV. TGF-beta1 and IGF-I gene variations in type 1 diabetes microangiopathic complications. J Diabetes Metab Disord. 2014;13(1):45.

19. Vaessen N, Heutink P, Janssen JA, Witteman JC, Testers L, Hofman A, et al. A polymorphism in the gene for IGF-I: functional properties and risk for type 2 diabetes and myocardial infarction. Diabetes. 2001;50(3):637-42.

20. Jones JI, Clemmons DR. Insulin-like growth factors and their binding proteins: biological actions. Endocr Rev. 1995;16(1):3-34.

21. Zhang J, Chen X, Zhang L, Peng Y. IGF1 gene polymorphisms associated with diabetic retinopathy risk in Chinese Han population. Oncotarget. 2017;8(50):88034-42.

22. Huuskonen A, Lappalainen J, Oksala N, Santtila M, Hakkinen K, Kyrolainen H, et al. Common genetic variation in the IGF1 associates with maximal force output. Med Sci Sports Exerc. 2011;43(12):2368-74.

23. Marini MA, Mannino GC, Fiorentino TV, Andreozzi F, Perticone F, Sesti G. A polymorphism at IGF1 locus is associated with anemia. Oncotarget. 2017;8(20):32398-406.

24. Szmuilowicz ED, Stuenkel CA, Seely EW. Influence of menopause on diabetes and diabetes risk. Nat Rev Endocrinol. 2009;5(10):553-8.

25. He L, Tang X, Li N, Wu YQ, Wang JW, Li JR, et al. Menopause with cardiovascular disease and its risk factors among rural Chinese women in Beijing: a population-based study. Maturitas. 2012;72(2):132-8.

26. Italia GdSPM. Risk factors for type 2 diabetes in women attending menopause clinics in Italy: a cross-sectional study. Climacteric. 2005;8(3):28793. 
27. Brand JS, van der Schouw YT, Onland-Moret NC, Sharp SJ, Ong KK, Khaw KT, et al. Age at menopause, reproductive life span, and type 2 diabetes risk: results from the EPIC-InterAct study. Diabetes Care. 2013;36(4):1012-9.

28. Adeva MM, Souto G. Diet-induced metabolic acidosis. Clin Nutr. 2011;30(4):416-21.

29. Li Y, He Y, Wang D, Gao X. Association between dietary acid-based load and obesity in Chinese adults. Federation of American Societies for Experimental Biology; 2012.

30. Bahadoran Z, Mirmiran P, Khosravi H, Azizi F. Associations between Dietary Acid-Base Load and Cardiometabolic Risk Factors in Adults: The Tehran Lipid and Glucose Study. Endocrinol Metab (Seoul). 2015;30(2):201-7.

31. Jayedi A, Shab-Bidar S. Dietary acid load and risk of type 2 diabetes: A systematic review and dose-response meta-analysis of prospective observational studies. Clin Nutr ESPEN. 2018;23:10-8.

32. Luis D, Huang X, Riserus U, Sjogren P, Lindholm B, Arnlov J, et al. Estimated dietary acid load is not associated with blood pressure or hypertension incidence in men who are approximately 70 years old. J Nutr. 2015;145(2):315-21.

33. Xu H, Jia T, Huang X, Riserus U, Cederholm T, Arnlov J, et al. Dietary acid load, insulin sensitivity and risk of type 2 diabetes in community-dwelling older men. Diabetologia. 2014;57(8):1561-8.

34. Lim SY, Zalilah MS, Chin YS, Ramachandran V, Chan YM. Dietary Acid Load, IGF-1 Single Nucleotide Polymorphism and Bone Resorption among Postmenopausal Chinese Women. Nutrients. 2018;10(7).

35. Armstrong T, Bull F. Development of the world health organization global physical activity questionnaire (GPAQ). Journal of Public Health. 2006;14(2):66-70.

36. Kyu HH, Bachman VF, Alexander LT, Mumford JE, Afshin A, Estep K, et al. Physical activity and risk of breast cancer, colon cancer, diabetes, ischemic heart disease, and ischemic stroke events: systematic review and dose-response meta-analysis for the Global Burden of Disease Study 2013. Bmj. 2016;354:i3857.

37. Organization WH. The Asia-Pacific perspective: redefining obesity and its treatment. Sydney: Health Communications Australia; 2000.

38. Institute for Public Health (IPH). National Health and Morbidity Survey 2014: Malaysian Adult Nutrition Survey;2014. 108 p.

39. Institute for Public Health. Report on Smoking Status among Malaysian Adults. Report of the National Health and Morbidity Survey 2015. Kuala Lumpur, Malaysia: IPH, Ministry of Health; 2015.

40. Mannino GC, Greco A, De Lorenzo C, Andreozzi F, Marini MA, Perticone F, et al. A fasting insulin-raising allele at IGF1 locus is associated with circulating levels of IGF-1 and insulin sensitivity. PLoS One. 2013;8(12):e85483.

41. Scott RA, Lagou V, Welch RP, Wheeler E, Montasser ME, Luan J, et al. Large-scale association analyses identify new loci influencing glycemic traits and provide insight into the underlying biological pathways. Nat Genet. 2012;44(9):991-1005.

42. Kostek MC, Devaney JM, Gordish-Dressman H, Harris TB, Thompson PD, Clarkson PM, et al. A polymorphism near IGF1 is associated with body composition and muscle function in women from the Health, Aging, and Body Composition Study. Eur J Appl Physiol. 2010;110(2):315-24.

43. Alberti KG, Eckel RH, Grundy SM, Zimmet PZ, Cleeman JI, Donato KA, et al. Harmonizing the metabolic syndrome: a joint interim statement of the International Diabetes Federation Task Force on Epidemiology and Prevention; National Heart, Lung, and Blood Institute; American Heart Association; World Heart Federation; International Atherosclerosis Society; and International Association for the Study of Obesity. Circulation. 2009;120(16):1640-5.

44. Heng KS, Hejar AR, Rushdan AZ, Loh SP. Prevalence of metabolic syndrome among staff in a Malaysian public university based on Harmonised, International Diabetes Federation and National Cholesterol Education Program Definitions. Malays J Nutr. 2013;19(1):77-86.

45. Rampal S, Mahadeva S, Guallar E, Bulgiba A, Mohamed R, Rahmat R, et al. Ethnic differences in the prevalence of metabolic syndrome: results from a multi-ethnic population-based survey in Malaysia. PLoS One. 2012;7(9):e46365.

46. Dehghan P, Abbasalizad Farhangi M. Dietary acid load, blood pressure, fasting blood sugar and biomarkers of insulin resistance among adults: Findings from an updated systematic review and meta-analysis. Int J Clin Pract. 2020;74(4):e13471.

47. Parohan M, Sadeghi A, Nasiri M, Maleki V, Khodadost M, Pirouzi A, et al. Dietary acid load and risk of hypertension: A systematic review and doseresponse meta-analysis of observational studies. Nutr Metab Cardiovasc Dis. 2019;29(7):665-75.

48. Chen SW, Chen ZH, Liang YH, Wang P, Peng JW. Elevated hypertension risk associated with higher dietary acid load: A systematic review and meta-analysis. Clin Nutr ESPEN. 2019;33:171-7.

49. Ma H, Sun G, Wang W, Zhou Y, Liu D, Tong Y, et al. Association Between Interleukin-6 -572 C>G and - 174 G>C Polymorphisms and Hypertension: A Meta-analysis of Case-control Studies. Medicine (Baltimore). 2016;95(2):e2416.

50. Akter S, Eguchi M, Kuwahara K, Kochi T, Ito R, Kurotani K, et al. High dietary acid load is associated with insulin resistance: The Furukawa Nutrition and Health Study. Clin Nutr. 2016;35(2):453-9.

51. Fagherazzi G, Vilier A, Bonnet F, Lajous M, Balkau B, Boutron-Rualt MC, et al. Dietary acid load and risk of type 2 diabetes: the E3N-EPIC cohort study. Diabetologia. 2014;57(2):313-20.

52. Gaede J, Nielsen T, Madsen ML, Toft U, Jorgensen T, Overvad K, et al. Population-based studies of relationships between dietary acidity load, insulin resistance and incident diabetes in Danes. Nutr J. 2018;17(1):91. 
53. Kiefte-de Jong JC, Li Y, Chen M, Curhan GC, Mattei J, Malik VS, et al. Diet-dependent acid load and type 2 diabetes: pooled results from three prospective cohort studies. Diabetologia. 2017;60(2):270-9.

54. Carnauba RA, Baptistella AB, Paschoal V, Hubscher GH. Diet-Induced Low-Grade Metabolic Acidosis and Clinical Outcomes: A Review. Nutrients. 2017;9(6).

55. McCarty MF. Acid-base balance may influence risk for insulin resistance syndrome by modulating cortisol output. Med Hypotheses. 2005;64(2):380-4.

56. Rylander R, Tallheden T, Vormann J. Acid-base conditions regulate calcium and magnesium homeostasis. Magnes Res. 2009;22(4):262-5.

57. Suliburska J, Cofta S, Gajewska E, Kalmus G, Sobieska M, Samborski W, et al. The evaluation of selected serum mineral concentrations and their association with insulin resistance in obese adolescents. Eur Rev Med Pharmacol Sci. 2013;17(17):2396-400.

58. Zingone F, Ciacci C. The value and significance of $25(\mathrm{OH})$ and $1,25(\mathrm{OH})$ vitamin D serum levels in adult coeliac patients: A review of the literature. Dig Liver Dis. 2018;50(8):757-60.

59. Ordonez FA, Santos F, Martinez V, Garcia E, Fernandez P, Rodriguez J, et al. Resistance to growth hormone and insulin-like growth factor-I in acidotic rats. Pediatr Nephrol. 2000;14(8-9):720-5.

60. Wang R, Xu D, Liu R, Zhao L, Hu L, Wu P. Microsatellite and Single Nucleotide Polymorphisms in the Insulin-Like Growth Factor 1 Promoter with Insulin Sensitivity and Insulin Secretion. Med Sci Monit. 2017;23:3722-36.

61. Yin YW, Sun QQ, Zhang BB, Hu AM, Wang Q, Liu HL, et al. The lack of association between interleukin- 6 gene -174 G/C polymorphism and the risk of type 1 diabetes mellitus: a meta-analysis of 18,152 subjects. Gene. 2013;515(2):461-5.

62. Gu T, Gu H, Hilding A, Ostenson C, Brismar K. DNA methylation analysis of the insulin-like growth factor-1 (IGF1) gene in Swedish men with normal glucose tolerance and type 2 diabetes. J Diabetes Metab. 2014;5(419):2.

63. Maalouf NM, Cameron MA, Moe OW, Adams-Huet B, Sakhaee K. Low urine pH: a novel feature of the metabolic syndrome. Clin J Am Soc Nephrol. 2007;2(5):883-8.

64. Murakami K, Livingstone MBE, Okubo H, Sasaki S. Higher dietary acid load is weakly associated with higher adiposity measures and blood pressure in Japanese adults: The National Health and Nutrition Survey. Nutr Res. 2017;44:67-75.

65. Murakami K, Sasaki S, Takahashi Y, Uenishi K. Association between dietary acid-base load and cardiometabolic risk factors in young Japanese women. Br J Nutr. 2008;100(3):642-51.

66. Welch AA, MacGregor AJ, Skinner J, Spector TD, Moayyeri A, Cassidy A. A higher alkaline dietary load is associated with greater indexes of skeletal muscle mass in women. Osteoporos Int. 2013;24(6):1899-908.

67. Kucharska AM, Szostak-Wegierek DE, Waskiewicz A, Piotrowski W, Stepaniak U, Pajak A, et al. Dietary acid load and cardiometabolic risk in the Polish adult population. Adv Clin Exp Med. 2018;27(10):1347-54.

68. Oana MC, Claudia B, Carmen D, Maria PA, Septimiu V, Claudiu M. The role of IL-6 572 C/G, 190 C/T, and 174 G/C gene polymorphisms in children's obesity. Eur J Pediatr. 2014;173(10):1285-96.

69. Slattery ML, Curtin K, Sweeney C, Wolff RK, Baumgartner RN, Baumgartner KB, et al. Modifying effects of IL-6 polymorphisms on body sizeassociated breast cancer risk. Obesity (Silver Spring). 2008;16(2):339-47.

70. Marginean C, Marginean CO, Banescu C, Melit L, Tripon F, lancu M. Impact of demographic, genetic, and bioimpedance factors on gestational weight gain and birth weight in a Romanian population: A cross-sectional study in mothers and their newborns: the Monebo study (STROBEcompliant article). Medicine (Baltimore). 2016;95(27):e4098.

71. van den Berg SW, Dolle ME, Imholz S, van der AD, van 't Slot R, Wijmenga C, et al. Genetic variations in regulatory pathways of fatty acid and glucose metabolism are associated with obesity phenotypes: a population-based cohort study. Int J Obes (Lond). 2009;33(10):1143-52.

\section{Tables}

Table 1 Demographic, anthropometrics, lifestyles, metabolic traits and genetic analysis of postmenopausal women ( $\mathrm{n=211)}$ 


\begin{tabular}{|c|c|c|}
\hline & Mean \pm SD or $\%$ & Range (min - max) \\
\hline \multicolumn{3}{|l|}{ Social demographics } \\
\hline Age (years) & $66.7 \pm 6.6$ & $51-85$ \\
\hline Postmenopausal (years) & $16.1 \pm 7.8$ & $5-43$ \\
\hline Education level (years) & $8 \pm 4.6$ & $0-18$ \\
\hline \multicolumn{3}{|l|}{ Lifestyles } \\
\hline Physical activity (MET min/week) & $1006.3 \pm 875.3$ & $0-4680$ \\
\hline Insufficiently active (<600 MET min/week) & 37.4 & \\
\hline Low active (600-3999 MET min/week) & 61.2 & \\
\hline Moderate active (4000-7999 MET min/week & 1.4 & \\
\hline High active (>8000 MET min/week) & 0 & \\
\hline \multicolumn{3}{|l|}{ Metabolic traits } \\
\hline $\mathrm{BMI}\left(\mathrm{kg} / \mathrm{m}^{2}\right)$ & $24.3 \pm 3.8$ & $16.2-37.5$ \\
\hline \multicolumn{3}{|l|}{ BMI/Obesity } \\
\hline No $\left(\mathrm{BMI}<30 \mathrm{~kg} / \mathrm{m}^{2}\right)$ & 92.9 & \\
\hline Yes $\left(\mathrm{BMI} \geq 30 \mathrm{~kg} / \mathrm{m}^{2}\right)$ & 7.1 & \\
\hline WC (cm) & $80.4 \pm 9.3$ & $58.4-116.7$ \\
\hline Normal $(\mathrm{WC}<80 \mathrm{~cm})$ & 50.7 & \\
\hline Abdominal obesity $(\mathrm{WC} \geq 80 \mathrm{~cm})$ & 49.3 & \\
\hline $\mathrm{SBP}(\mathrm{mmHg})$ & $140 \pm 20.2$ & $92-214$ \\
\hline Normal (SBP < $130 \mathrm{mmHg})$ & 31.8 & \\
\hline Hypertension (SBP $\geq 130$ mmHg) & 68.2 & \\
\hline $\mathrm{DBP}(\mathrm{mmHg})$ & $77 \pm 10.2$ & $51-103$ \\
\hline Normal (DBP < 85 mmHg) & 76.8 & \\
\hline Hypertension (DBP $\geq 85$ mmHg) & 23.2 & \\
\hline Fasting blood glucose (mmol/L) & $5.9 \pm 0.8$ & $4.4-9.2$ \\
\hline Normal (FBG < $5.6 \mathrm{mmol} / \mathrm{L})$ & 40.8 & \\
\hline Hyperglycemia (FBG $\geq 5.6 \mathrm{mmol} / \mathrm{L})$ & 59.2 & \\
\hline Total-C (mg/dL) & $5.8 \pm 1.1$ & $2.7-9.4$ \\
\hline $\mathrm{HDL}-\mathrm{C}(\mathrm{mg} / \mathrm{dL})$ & $1.6 \pm 0.4$ & $0.8-3$ \\
\hline Normal ( $\geq 1.3 \mathrm{mmol} / \mathrm{L})$ & 89.1 & \\
\hline Dyslipidemia (< $1.3 \mathrm{mmol} / \mathrm{L})$ & 10.9 & \\
\hline LDL-C (mg/dL) & $3.5 \pm 1$ & $0.9-7.1$ \\
\hline $\mathrm{TG}(\mathrm{mg} / \mathrm{dL})$ & $1.3 \pm 0.6$ & $0.4-3.8$ \\
\hline Normal (< 1.7 mmol/L) & 76.8 & \\
\hline Dyslipidemia ( $\geq 1.7$ mmol/L) & 23.2 & \\
\hline \multicolumn{3}{|l|}{ Dietary intake } \\
\hline PRAL (mEq/day) & $13.8 \pm 19.1$ & $-49.5-85.3$ \\
\hline Total energy intake (kcal) & $1481 \pm 523.6$ & $505.8-3580.1$ \\
\hline \multicolumn{3}{|l|}{ Genetic analysis } \\
\hline SNP rs35767 (genotype) (\%) & & \\
\hline
\end{tabular}

Page 10/13 


\begin{tabular}{|c|c|}
\hline TT & 9.4 \\
\hline CT & 42.7 \\
\hline CC & 47.9 \\
\hline SNP rs7136446 (genotype) (\%) \\
\hline TT & 67.3 \\
\hline CT & 28.0 \\
\hline CC & 4.7 \\
\hline SNP rs 1800796 (genotype) (\%) \\
\hline CC & 2.8 \\
\hline CG & 41.3 \\
\hline GG & 55.9 \\
\hline
\end{tabular}

MET: metabolic equivalent; BMI: body mass index; WC: waist circumference; SBP: systolic blood pressure, DBP: diastolic blood pressure, Total-C: total cholesterol, HDL-C: high-density lipoproteins cholesterol, LDL-C: low-density lipoprotein cholesterol, TG: triglyceride

Table 2 Demographic and metabolic traits according to SNPs rs35767, rs7136446 and rs1800796

\begin{tabular}{|c|c|c|c|c|c|c|}
\hline & \multicolumn{2}{|l|}{ SNP rs35767 } & \multicolumn{2}{|c|}{ SNP rs7136446 } & \multicolumn{2}{|c|}{ SNP rs1800796 } \\
\hline & $\mathrm{CC}(\mathrm{n}=101)$ & $C T+T T(n=110)$ & $\mathrm{TT}(\mathrm{n}=142)$ & $C T+C C(n=69)$ & $\operatorname{CC}(n=118)$ & $C G+G G(n==93)$ \\
\hline Age (years) & $66.8 \pm 6.9$ & $66.6 \pm 6.4$ & $67.1 \pm 6.8$ & $66 \pm 6.1$ & $67.4 \pm 7.2$ & $65.9 \pm 5.6$ \\
\hline Duration of menopause (years) & $16.6 \pm 8.4$ & $15.7 \pm 7.2$ & $16.3 \pm 7.4$ & $15.9 \pm 8.6$ & $16.8 \pm 8.4$ & $15.3 \pm 6.9$ \\
\hline Duration of education (years) & $7.5 \pm 4.4$ & $8.4 \pm 4.8$ & $8.2 \pm 4.5$ & $7.5 \pm 4.8$ & $7.4 \pm 4.5$ & $8.6 \pm 4.6$ \\
\hline BMI $\left(\mathrm{kg} / \mathrm{m}^{2}\right)$ & $24.3 \pm 3.7$ & $24.4 \pm 3.99$ & $24.5 \pm 3.7$ & $24 \pm 3.9$ & $24.5 \pm 3.9$ & $24.1 \pm 3.7$ \\
\hline Waist circumference (cm) & $80.2 \pm 88$ & $80.6 \pm 9.7$ & $80.3 \pm 9.1$ & $80.6 \pm 9.6$ & $80.9 \pm 9.7$ & $79.7 \pm 8.6$ \\
\hline $\mathrm{SBP}(\mathrm{mmHg})$ & $138.6 \pm 21$ & $141.3 \pm 19.5$ & $140.5 \pm 18.8$ & $138.9 \pm 23$ & $140.9 \pm 20.8$ & $138.8 \pm 19.4$ \\
\hline $\mathrm{DBP}(\mathrm{mmHg})$ & $77.1 \pm 10.2$ & $76.9 \pm 10.3$ & $76.9 \pm 10$ & $77.2 \pm 10.8$ & $77.3 \pm 10.2$ & $76.7 \pm 10.3$ \\
\hline Fasting blood glucose (mmol/L) & $5.99 \pm 0.8$ & $5.9 \pm 0.9$ & $5.9 \pm 0.9$ & $5.8 \pm 0.8$ & $5.9 \pm 0.8$ & $5.9 \pm 0.9$ \\
\hline Total-C (mg/dL) & $5.8 \pm 1$ & $5.8 \pm 1.2$ & $5.8 \pm 1.1$ & $5.7 \pm 1.1$ & $5.8 \pm 1.2$ & $5.8 \pm 1$ \\
\hline HDL-C (mg/dL) & $1.7 \pm 0.4$ & $1.6 \pm 0.3$ & $1.6 \pm 0.3$ & $1.7 \pm 0.4$ & $1.6 \pm 0.4$ & $1.6 \pm 0.4$ \\
\hline LDL-C (mg/dL) & $3.5 \pm 0.9$ & $1.6 \pm 1.1$ & $3.6 \pm 1$ & $3.5 \pm 1$ & $3.6 \pm 1.1$ & $3.5 \pm 1$ \\
\hline $\mathrm{TG}(\mathrm{mg} / \mathrm{dL})$ & $1.4 \pm 0.6$ & $1.3 \pm 0.6$ & $1.4 \pm 0.6$ & $1.3 \pm 0.6$ & $1.3 \pm 0.6$ & $1.4 \pm 0.7$ \\
\hline
\end{tabular}

Data were presented as means \pm S.D, performed by independent t-test, ${ }^{*} p<0.05$ compared with major allele for each genotype.

Table 3 Hierarchical Linear regression analyses on gene-DAL interaction effects on metabolic traits 


\begin{tabular}{|c|c|c|c|c|c|c|c|c|c|c|c|c|}
\hline \multirow[t]{2}{*}{ Variable } & \multicolumn{2}{|l|}{ SBP } & \multicolumn{2}{|l|}{ DBP } & \multicolumn{2}{|l|}{ WC } & \multicolumn{2}{|l|}{ FBG } & \multicolumn{2}{|l|}{ TG } & \multicolumn{2}{|c|}{$\begin{array}{l}\text { HDL and } \\
\text { cholesterol ratio }\end{array}$} \\
\hline & $\begin{array}{l}B \\
\text { value } \\
\pm S E\end{array}$ & $\begin{array}{l}\mathrm{F} \\
\text { change }\end{array}$ & $\begin{array}{l}\text { B } \\
\text { value } \\
\pm S E\end{array}$ & $\begin{array}{l}\text { F } \\
\text { change }\end{array}$ & $\begin{array}{l}B \\
\text { value } \\
\pm S E\end{array}$ & $\begin{array}{l}\text { F } \\
\text { change }\end{array}$ & $\begin{array}{l}B \\
\text { value } \\
\pm S E\end{array}$ & $\begin{array}{l}\text { F } \\
\text { change }\end{array}$ & $\begin{array}{l}\text { B } \\
\text { value } \\
\pm \text { SE }\end{array}$ & $\begin{array}{l}\text { F } \\
\text { change }\end{array}$ & $\begin{array}{l}\text { B } \\
\text { value } \\
\pm S E\end{array}$ & $\begin{array}{l}\mathrm{F} \\
\text { change }\end{array}$ \\
\hline $\begin{array}{l}\text { Step } 1 \text { (adjusted } \\
\text { variables) }\end{array}$ & & $22.291^{\star *}$ & & $10.162^{\star \star}$ & & $17.575^{\star \star}$ & & $8.443^{\star *}$ & & $18.005^{* *}$ & & $17.250^{* *}$ \\
\hline Age & $\begin{array}{l}0.371 \\
\pm \\
0.184^{\star *}\end{array}$ & & $\begin{array}{l}0.012 \\
\pm \\
0.102\end{array}$ & & & & $\begin{array}{l}0.185 \\
\pm \\
0.001^{*}\end{array}$ & & & & $\begin{array}{l}-0.181 \\
\pm \\
0.013^{*}\end{array}$ & \\
\hline BMI & $\begin{array}{l}0.388 \\
\pm \\
0.301^{\star *}\end{array}$ & & $\begin{array}{l}0.392 \\
\pm \\
0.167^{\star \star}\end{array}$ & & & & $\begin{array}{l}0.209 \\
\pm \\
0.001^{*}\end{array}$ & & & & & \\
\hline $\begin{array}{l}\text { Total } \\
\text { cholesterol }\end{array}$ & $\begin{array}{l}0.169 \\
\pm \\
1.100^{*}\end{array}$ & & $\begin{array}{l}0.154 \\
\pm \\
0.609^{*}\end{array}$ & & & & $\begin{array}{l}-0.191 \\
\pm \\
0.004^{*}\end{array}$ & & & & & \\
\hline FBG & $\begin{array}{l}0.019 \\
\pm \\
17.215\end{array}$ & & $\begin{array}{l}-0.050 \\
\pm \\
9.532\end{array}$ & & $\begin{array}{l}0.220 \\
\pm \\
7.793^{*}\end{array}$ & & & & $\begin{array}{l}0.080 \\
\pm \\
0.508\end{array}$ & & & \\
\hline SBP & & & & & $\begin{array}{l}0.226 \\
\pm \\
0.029^{*}\end{array}$ & & $\begin{array}{l}0.023 \\
\pm \\
0.000\end{array}$ & & $\begin{array}{l}0.117 \\
\pm \\
0.002\end{array}$ & & & \\
\hline \multicolumn{2}{|l|}{$\begin{array}{l}\text { Year(s) of } \\
\text { education }\end{array}$} & & & & $\begin{array}{l}-0.192 \\
\pm \\
0.123^{*}\end{array}$ & & & & & & $\begin{array}{l}0.100 \\
\pm \\
0.019\end{array}$ & \\
\hline TG & & & & & $\begin{array}{l}0.229 \\
\pm \\
0.961^{\star *}\end{array}$ & & & & & & $\begin{array}{l}0.411 \\
\pm \\
0.134^{\star *}\end{array}$ & \\
\hline $\begin{array}{l}\text { HDL and } \\
\text { cholesterol } \\
\text { ratio }\end{array}$ & & & & & & & & & $\begin{array}{l}0.397 \\
\pm \\
0.027^{\star *}\end{array}$ & & & \\
\hline WC & & & & & & & & & $\begin{array}{l}0.185 \\
\pm \\
0.004^{*}\end{array}$ & & & \\
\hline \multicolumn{2}{|l|}{$\begin{array}{l}\text { Serum } \\
25(\mathrm{OH}) \text { vitamin } \\
D\end{array}$} & & & & & & & & $\begin{array}{l}-0.176 \\
\pm \\
0.002^{*}\end{array}$ & & & \\
\hline \multicolumn{2}{|l|}{$\begin{array}{l}\text { Physical } \\
\text { activity }\end{array}$} & & & & & & & & & & $\begin{array}{l}0.107 \\
\pm \\
0.000\end{array}$ & \\
\hline \multicolumn{13}{|c|}{$\begin{array}{l}\text { PRAL and SNP rs35767 } \\
\text { Model }\end{array}$} \\
\hline \multicolumn{2}{|c|}{$\begin{array}{l}\text { Step } 2 \text { (DAL and gene } \\
\text { main effects) }\end{array}$} & 1.150 & & 0.010 & & 0.733 & & 2.730 & & 0.071 & & 1.112 \\
\hline $\begin{array}{l}\text { PRAL } \\
\text { (mEq/day) }\end{array}$ & $\begin{array}{l}-0.047 \\
\pm \\
0.063\end{array}$ & & $\begin{array}{l}0.008 \\
\pm \\
0.035\end{array}$ & & $\begin{array}{l}-0.062 \\
\pm \\
0.030\end{array}$ & & $\begin{array}{l}0.149 \\
\pm \\
0.000^{*}\end{array}$ & & $\begin{array}{l}-0.011 \\
\pm \\
0.002\end{array}$ & & $\begin{array}{l}-0.045 \\
\pm \\
0.004\end{array}$ & \\
\hline $\begin{array}{l}\text { SNP rs35767 } \\
(0=\mathrm{CC}, 1=\mathrm{TT} \\
+\mathrm{TC})\end{array}$ & $\begin{array}{l}0.077 \\
\pm \\
2.348\end{array}$ & & $\begin{array}{l}-0.006 \\
\pm \\
1.307\end{array}$ & & $\begin{array}{l}0.045 \\
\pm \\
1.125\end{array}$ & & $\begin{array}{l}-0.027 \\
\pm \\
0.009\end{array}$ & & $\begin{array}{l}-0.019 \\
\pm \\
0.072\end{array}$ & & $\begin{array}{l}-0.077 \\
\pm \\
0.163\end{array}$ & \\
\hline \multicolumn{2}{|c|}{$\begin{array}{l}\text { Step } 3 \text { (DAL*gene } \\
\text { interactions) }\end{array}$} & 0.107 & & 0.083 & & 0.005 & & 0.768 & & 1.443 & & 0.047 \\
\hline $\begin{array}{l}\mathrm{PRAL} \text { * IGF1 } \\
(\mathrm{TT}+\mathrm{TC})\end{array}$ & $\begin{array}{l}0.033 \\
\pm \\
0.126\end{array}$ & & $\begin{array}{l}-0.032 \\
\pm \\
0.070\end{array}$ & & $\begin{array}{l}0.008 \\
\pm \\
0.060\end{array}$ & & $\begin{array}{l}-0.097 \\
\pm \\
0.001\end{array}$ & & $\begin{array}{l}0.122 \\
\pm \\
0.004\end{array}$ & & $\begin{array}{l}0.023 \\
\pm \\
0.009\end{array}$ & \\
\hline \multicolumn{13}{|c|}{$\begin{array}{l}\text { PRAL and SNP } \\
\text { rs7136446 Model }\end{array}$} \\
\hline \multicolumn{2}{|c|}{$\begin{array}{l}\text { Step } 2 \text { (DAL and gene } \\
\text { main effects) }\end{array}$} & 0.395 & & 0.296 & & 0.521 & & 2.797 & & 0.451 & & 0.511 \\
\hline
\end{tabular}




\begin{tabular}{|c|c|c|c|c|c|c|c|c|c|c|c|c|}
\hline $\begin{array}{l}\text { PRAL } \\
\text { (mEq/day) }\end{array}$ & $\begin{array}{l}-0.043 \\
\pm \\
0.063\end{array}$ & & $\begin{array}{l}0.009 \\
\pm \\
0.035\end{array}$ & & $\begin{array}{l}-0.058 \\
\pm \\
0.030\end{array}$ & & $\begin{array}{l}0.149 \\
\pm \\
0.000^{*}\end{array}$ & & $\begin{array}{l}-0.014 \\
\pm \\
0.002\end{array}$ & & $\begin{array}{l}-0.047 \\
\pm \\
0.004\end{array}$ & \\
\hline $\begin{array}{l}\text { SNP } \\
\text { rs7136446 (0 } \\
=\text { TT, 1 = CC + } \\
\text { CT) }\end{array}$ & $\begin{array}{l}0.029 \\
\pm \\
2.528\end{array}$ & & $\begin{array}{l}0.049 \\
\pm \\
1.400\end{array}$ & & $\begin{array}{l}0.021 \\
\pm \\
1.194\end{array}$ & & $\begin{array}{l}0.036 \\
\pm \\
0.010\end{array}$ & & $\begin{array}{l}-0.055 \\
\pm \\
0.077\end{array}$ & & $\begin{array}{l}0.039 \\
\pm \\
0.176\end{array}$ & \\
\hline $\begin{array}{l}\text { Step } 3 \text { (DAL*gen } \\
\text { interactions) }\end{array}$ & & 3.814 & & 2.082 & & 0.525 & & 0.612 & & 0.217 & & 0.048 \\
\hline $\begin{array}{l}\text { PRAL* SNP } \\
\text { rs7136446 } \\
(\mathrm{CC}+\mathrm{CT})\end{array}$ & $\begin{array}{l}-0.156 \\
\pm \\
0.144\end{array}$ & & $\begin{array}{l}-0.127 \\
\pm \\
0.080\end{array}$ & & $\begin{array}{l}-0.061 \\
\pm \\
0.069\end{array}$ & & $\begin{array}{l}0.070 \\
\pm \\
0.001\end{array}$ & & $\begin{array}{l}0.038 \\
\pm \\
0.004\end{array}$ & & $\begin{array}{l}0.018 \\
\pm \\
0.010\end{array}$ & \\
\hline \multicolumn{13}{|l|}{$\begin{array}{l}\text { PRAL and SNP } \\
\text { rs1800796 Model }\end{array}$} \\
\hline \multicolumn{2}{|c|}{$\begin{array}{l}\text { Step } 2 \text { (DAL and gene } \\
\text { main effects) }\end{array}$} & 0.389 & & 0.007 & & 0.657 & & 2.649 & & 1.567 & & 1.880 \\
\hline $\begin{array}{l}\text { PRAL } \\
\text { (mEq/day) }\end{array}$ & $\begin{array}{l}-0.045 \\
\pm \\
0.063\end{array}$ & & $\begin{array}{l}0.007 \\
\pm \\
0.035\end{array}$ & & $\begin{array}{l}-0.057 \\
\pm \\
0.030\end{array}$ & & $\begin{array}{l}0.147 \\
\pm \\
0.000^{*}\end{array}$ & & $\begin{array}{l}-0.016 \\
\pm \\
0.002\end{array}$ & & $\begin{array}{l}-0.041 \\
\pm \\
0.004\end{array}$ & \\
\hline $\begin{array}{l}\text { SNP } \\
\text { rs } 1800796(0 \\
=\text { CC, } 1=\text { GG + } \\
\text { CG) }\end{array}$ & $\begin{array}{l}0.029 \\
\pm \\
2.398\end{array}$ & & $\begin{array}{l}0.003 \\
\pm \\
1.331\end{array}$ & & $\begin{array}{l}-0.038 \\
\pm \\
1.136\end{array}$ & & $\begin{array}{l}0.010 \\
\pm \\
0.010\end{array}$ & & $\begin{array}{l}0.103 \\
\pm \\
0.071\end{array}$ & & $\begin{array}{l}-0.108 \\
\pm \\
0.165\end{array}$ & \\
\hline \multicolumn{2}{|l|}{$\begin{array}{l}\text { Step } 3 \text { (DAL* }{ }^{*} \text { ene } \\
\text { interactions) }\end{array}$} & $4.222^{*}$ & & 0.536 & & 0.133 & & 1.236 & & 0.876 & & 0.944 \\
\hline $\begin{array}{l}\text { PRAL* SNP } \\
\text { rs1800796 } \\
(\text { GG + CG) }\end{array}$ & $\begin{array}{l}0.194 \\
\pm \\
0.124^{*}\end{array}$ & & $\begin{array}{l}0.076 \\
\pm \\
0.069\end{array}$ & & $\begin{array}{l}0.036 \\
\pm \\
0.060\end{array}$ & & $\begin{array}{l}-0.117 \\
\pm \\
0.001\end{array}$ & & $\begin{array}{l}0.090 \\
\pm \\
0.004\end{array}$ & & $\begin{array}{l}-0.096 \\
\pm \\
0.009\end{array}$ & \\
\hline
\end{tabular}

Note: ${ }^{*} p<0.05 ;{ }^{* \star} p<0.001$

\section{Figures}

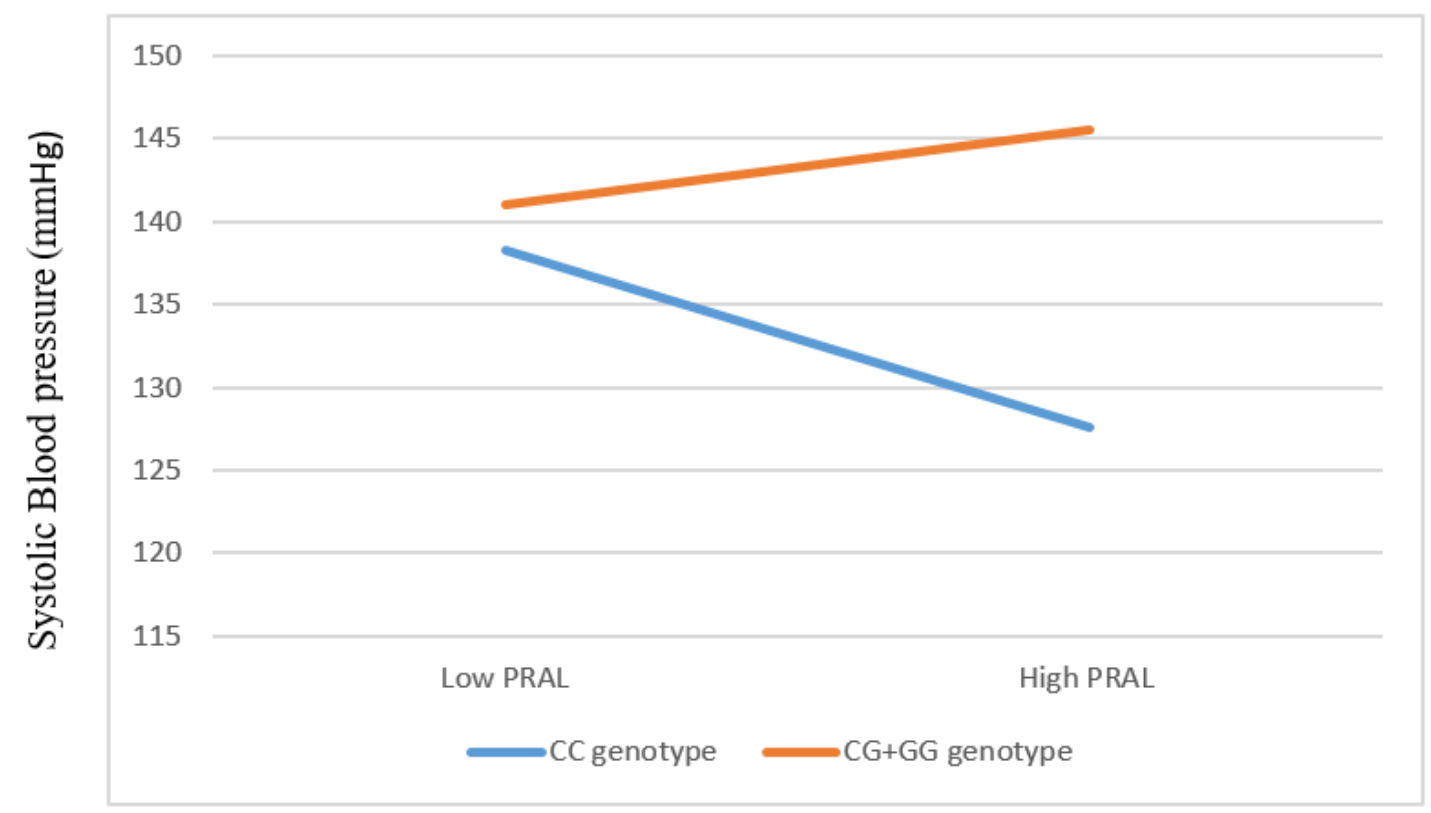

Figure 1

Interaction effect between PRAL (mEq/d) and SNP rs1800796 on SBP. An overall P value was obtained by hierarchical multiple linear regression. Estimates were adjusted for age (continuous), BMI (continuous), total cholesterol (continuous) and FBG (continuous). 